\title{
人工衛星構造材料の電子線照射に伴う帯電特性
}

\author{
正員 小松原 実 (岡山商大) 正員 石井 勝 (東京大)

\section{Charging Characteristics of Construction Materials of Spacecraft Irradiated by Electron Beam}

Minoru Komatsubara, Member (Okayama Shouka University), Masaru Ishii, Member (The University of Tokyo)

\begin{abstract}
Composite materials like carbon fiber reinforced plastics (CFRP) or fiber reinforced plastics (FRP) are used for construction materials of spacecraft. In case fiber reinforced plastics (FRP) are used for construction materials of spacecraft, germanium (Ge) sputtered FRP is used because of its ability of thermal control. On an orbit of high altitude, the charging on polymer materials can cause troubles in measurements on spacecraft.

To investigate the charging phenomena on these kinds of materials in vacuum, electron beams are irradiated on test pieces of FRP, Ge-sputtered FRP and CFRP. The experiments are conducted in a high-vacuum chamber attached with an electron beam gun.

The results show that the absolute values of the surface potential of Ge-sputtered FRP keep lower values than that of FRP. The irradiation on negatively charged Ge-sputtered FRP decreases the magnitude of the surface potential. Ge-sputtered FRP with a thicker layer of Ge shows a similar and pronounced tendency. Irradiation with higher current density also causes more rapid decrease of the potential. The results for CFRP also show low values of the saturated surface potential. These characteristics are different from those of simple polymer test pieces such as a fluoroethylenepropylene (FEP) film. In spite that the penetration depth of electrons is confined in Ge layer, the surface potential of Ge-sputtered FRP shows lower values than the potential expected for single materials. The mechanism of this phenomenon seems to be related to secondary electron emission.
\end{abstract}

キーワード: FRP, 帯電, 蒸着, 真空, 2 次電子

\section{1. はじめに}

人工衛星の構造材料には, 軽量であることと高強度であ ることが同時に要求される。このような用途に，エポキシ 樹脂に炭素繊維を加えて材料の強度を上げた CFRPや，ガラ ス繊維を加えた FRP が用いられる場合がある。電子線等の 荷電粒子の照射を受ける宇宙環境においては，このような 人工衛星の外側に使用される材料の带電現象 ${ }^{(1)}$ は, 人工衛星 の信頼性に強い影響を及ぼしうる。人工衛星から張り出し て設置されるアンテナなどの支持構造物として用いられる FRP 等が帯電すると, 計測などの機能に障害が発生する恐 れがあるが，電磁波を透過させる必要性から，金属材料を この用途に用いることができない場合もある。

このような材料の表面は，太陽光線を受けた場合と日陰 になった場合とで, その温度差が大きくなり人工衛星内部 の装置に影響を与えることがある。そのような大きな温度 差の発生を防ぐために熱制御を行う必要があり，FRP の表 面に電磁波の透過の障害にならない程度の厚さでゲルマニ ウム $(\mathrm{Ge})$ 蒸着膜を形成する方法が用いられる。しかし， CFRP やFRP のような複合材料や，それらに金属蒸着膜を形
成したものに対して，電子線が照射された場合の帯電現象 に関する報告は，ほとんどないのが現状である。

これまで，筆者らは FEP などの高分子フィルムが電子線 照射を受けた場合の帯電現象に関して, その特性に関する 実験結果および機構に関する検討結果を報告してきたが ${ }^{(2)}$, 本研究では，半導体と高分子の複合構造材料である CFRP, FRP, Ge 蒸着 FRP, Al 蒸着 FEP の各試料に対して真空容器 中において電子線照射を行い，その測定結果に基づき，単 一の高分子材料と比較した場合の各試料の带電特性とその 機構に関して検討を行った。

\section{2. 実験装置および方法}

CFRP 試料には，厚さ約 $0.5 \mathrm{~mm}$ ，大きさ $5 \mathrm{~cm} \times 5 \mathrm{~cm}$ のもの を用いた。試料表面は起伏が激しく，抵抗率の測定が困難 であるため行なっていないが，後述の帯電後の電位の緩和 速度の測定結果から, 本研究での議論の対象である到達電 位の值には導電電流の影響はほとんどないものと判断され 万。

FRP 試料には, 厚さ $1 \mathrm{~mm}$, 大きさ $5 \mathrm{~cm} \times 5 \mathrm{~cm}$ の FP 板に, 
厚さ $10 \mathrm{~nm}$ および $50 \mathrm{~nm} て ゙ ~ G e$ 蒸着を行ったもの, および蒸 着を行っていないものの3種類使用した。Ge 蒸着 FRP は 蒸着後に試料端部を切断してあり，Ge は端部には蒸着して いないので, 端部を通じて漏れる電流はきわめて小さい。 これは表面電位の緩和(後述)がきわめて遅いことからも確認 されている。また，CFRP と同様に到達電位八の導電電流の 影響はほとんどないものと考えられる。

試料は, 真空容器中で電子線照射を行い，一定時間每に 照射を停止してその表面電位を非接触で測定する。このた めに用いた真空容器は, 直径 $40 \mathrm{~cm}$, 高さ $47 \mathrm{~cm}$ のステンレ 又鋼製容器で，上部に設置された電子銃には負電在がかけ られ，これにより接地されたアルミニウム製試料台に対し て加速された電子線が照射される。真空容器の概略を図 1 に 示す。

試料の表面電位は，非接触の表面電位計 (Trek 社製 Model341 型, 测定可能範囲土20kV)のプローブを試料表面上 方約 $2 \mathrm{~mm}$ の高さで，試料中央部付近に移動させて測定した。 この測定方法においては，接地電位にある試料台の影響は 無視しうるものである ${ }^{(2)}$ 。

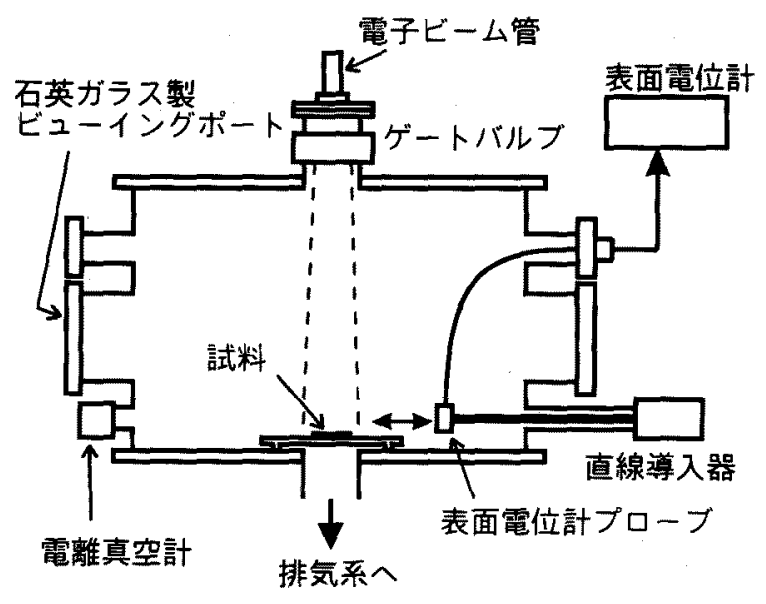

図 1 真空装置概略

Fig. 1. Vacuum chamber.

\section{3. 実験結果および考察}

<3.1> Ge10nm 蒸替 FRP の結果蒸着なしの試料に対し て電子線照射をおこなった場合の表面電位は, 電流密度

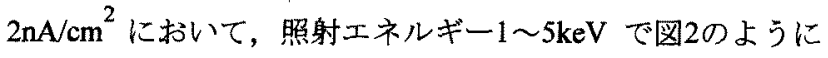
なった。

照射エネルギーが $1.5 \mathrm{keV}$ 以上では，表面電位はほほ照射 エネルギーと同じ割合で増加している。また，照射 30 秒の 時点でほぼ電位の絶対值の上昇は飽和していることがわか る。また，照射エネルギーと表面電位の差は，1.3〜 $1.4 \mathrm{kV}$ と なっている。一方, 人工衛星表面材料として使われる fluoroethylenepropylene(FEP)や polyethyleneterephthalate (PET) ではこの值は約 $2 \mathrm{kV}$ である ${ }^{(2)}$ 。FEP やPET のような高分子 材料の場合， $127 \mu \mathrm{m}$ 程度以上の厚さの場合には，内部を

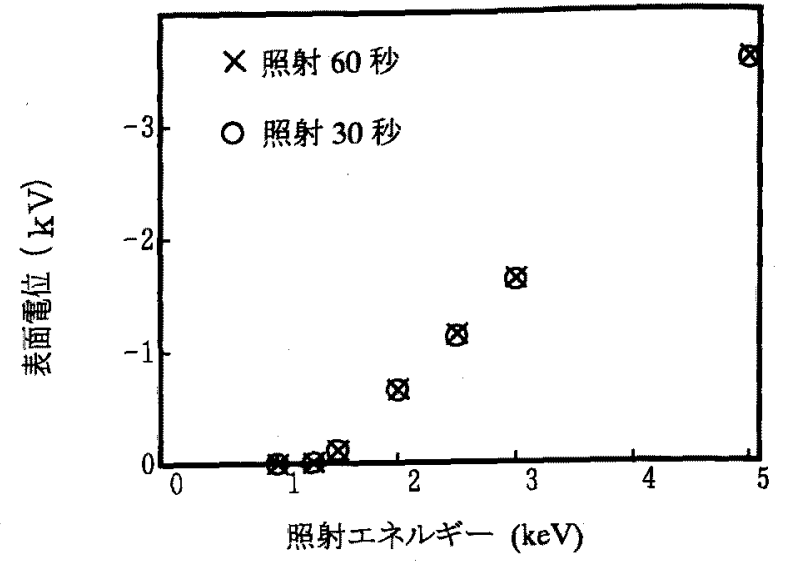

図2

FRP 試料の表面電位の照射電子線エネル ギ一依存性

Fig. 2. Surface potential of FRP dependent on irradiation energy.

流れる導電電流が到達電位の值に及ぼす影響はほとんどな い(2)。したがって，FEPや PET に比較すると，今回使用し た FRP はFEPやPETよりも照射された電子線のエネルギー の值に近い電位まで帯電しやすい試料であることになる。

これに対して, Gelonm 蒸着 FRP の場合の, 電流密度 $1 \mathrm{nA} / \mathrm{cm}^{2}$ での電子線照射 60 秒後の表面電位の測定結果を図 3 に示す。

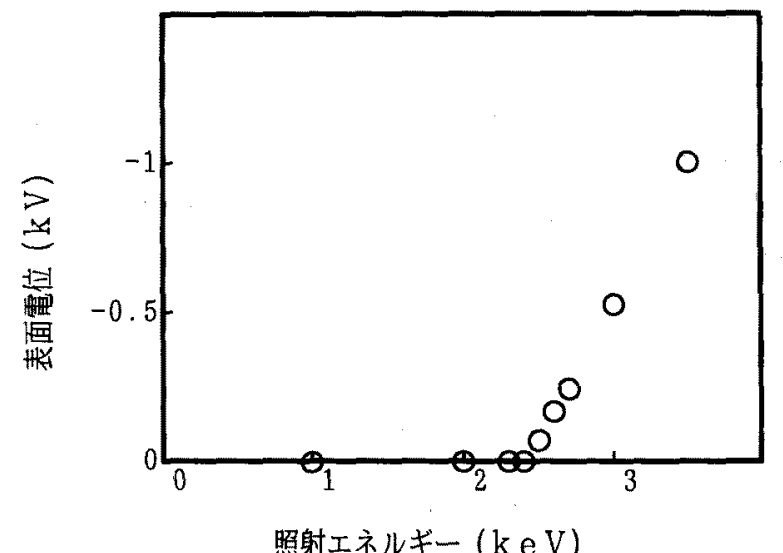

図3. Ge10nm 蒸着 FRP の表面電位の照射電子線エネル ギ一依存性

Fig. 3. Surface potential of FRP sputtered with Ge of 10 $\mathrm{nm}$ thick dependent on irradiation energy.

Ge 蒸着 FRP の場合には，電子線照射エネルギーが $2.4 \mathrm{keV}$ までは，表面電位はほぼ 0V のままであることがわかる。Ge 蒸着なしの FRP の場合と比べて，電子線照射エネルギーが 約 $1 \mathrm{keV}$ 高くなるまでは，表面の帯電が発生しないことにな る。なお， Ge 蒸着 FRPに $3.5 \mathrm{keV}, 1 \mathrm{nA} / \mathrm{cm}^{2}$ で 60 秒間の電 子線照射を行ない，-1015V の带電を生じさせた後，電子線 照射を停止して，電位の変化を測定した結果， 3 分経過時 
でー999V， 5 分経過時で $-990 \mathrm{~V}$ であり，電位の緩和速度は 小さいことがわがる。

次に，試料表面がー $1 \mathrm{kV} に$ 帯電した状態で， $2 \mathrm{keV}$ ， $0.1 \mathrm{n} \mathrm{A} / \mathrm{cm}^{2}$ および, $0.3 \mathrm{nA} / \mathrm{cm}^{2}$ の電子線照射をおこなった場 合の表面電位の時間変化を図4に示す。

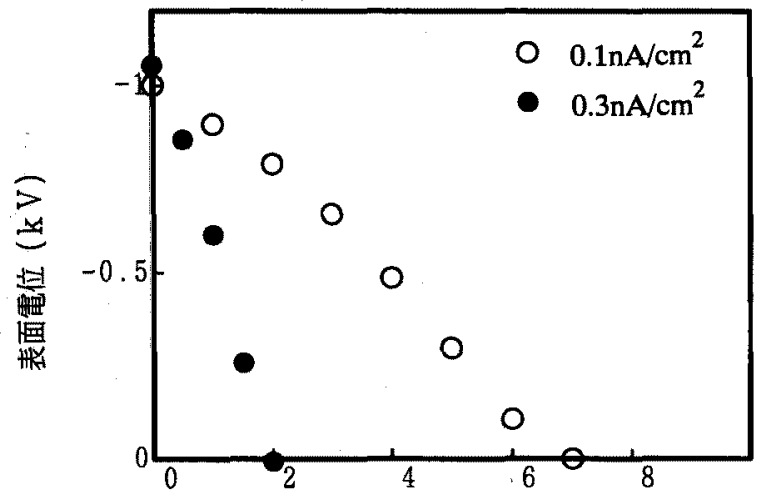

照射㭙間 $(\mathrm{m}$ i $\mathrm{n})$

図4 $2 \mathrm{keV}$ の電子線照射時の Ge10nm 蒸着 FRP の表面 電位の時間変化

Fig. 4. Time variation of surface potential of FRP sputtered with $\mathrm{Ge}$ of $10 \mathrm{~nm}$ thick irradiated by electron beam of $2 \mathrm{keV}$.

$0.1 \mathrm{nA} / \mathrm{cm}^{2}$ の場合で 6 分前後, $0.3 \mathrm{nA} / \mathrm{cm}^{2}$ の場合では 2 分 以内に，表面の带電はほぼなくなっており，電流密度が大 きいほど急速に帯電が緩和されている。これは，2次電子 として試料表面から電子が放出され，表面電位を緩和して いるものと考えることができる。

さらに, 表面電位をー $1 \mathrm{kV}$ に帯電させた Ge10nm 蒸着 FRP 試料に対して，電流密度 $1 \mathrm{nA} / \mathrm{cm}^{2}$ において何通りかのエネ ルギーの電子線照射を 1 分間おこなった場合の，残留表面 電位を测定した結果を図5に示す。

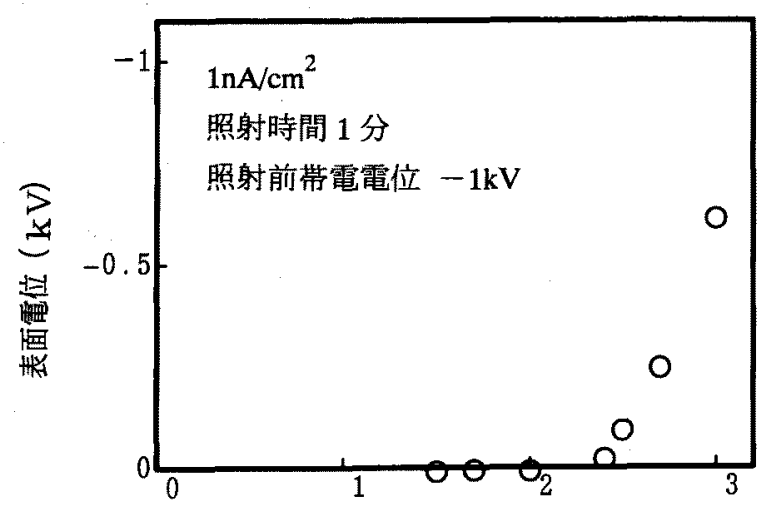

照射エネルギー $(\mathrm{keV})$

図5照射エネルギーと帯電させた Ge10nm 蒸着 FRP の 残留表面電位の関保

Fig. 5. Relationship between irradiation energy and residual potential of pre-charged FRP sputtered with $\mathrm{Ge}$ of $10 \mathrm{~nm}$ Thick.
照射エネルギーが $2.4 \mathrm{keV}$ 付近までは，表面電位はほぼ $0 \mathrm{~V}$

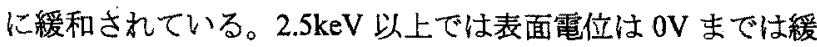
和されず，照射エネルギ一の值が增加するに伴い，表面電 位の絶対值む上昇している。

一般に，高分子材料表面に電子線照射をおこなった場合 には，2次電子放出が関係するために，表面電位の飽和時 の值は照射エネルギーに対して, 絶対值で $2 \mathrm{kV}$ 程度低い電 位となる。このときの表面電位と照射エネルギーの差は, 2 次電子と後方散乱電子の総量の入射電子に対する収量 (yield)が 1 になる時の電子線エネルギーと関係し，2次電子 放出特性から計算により求めた表面電位と測定值は比較的 よく一致する ${ }^{(2)}$ 。

yield と照射エネルギーの関係を表す曲線の最大值となる 部分を 1 として，Ge の実験データをもとに描かれた規格化 2 次電子放出比曲線 ${ }^{(4)}$ 用いて, 今回使用した Ge の場合に yield が 1 となるときの照射エネルギーを求めてみる。yield が最大值をとるときの照射エネルギー $E_{m}$ は $300 \sim 500 \mathrm{~V}$ ，そ の時の yield の最大值は $1.1 \sim 1.3$ であり ${ }^{(3)}$, これより， $E_{m}$ を $400 \mathrm{eV}$ ，その場合の yield の值を 1.1 と仮定する。規格化 2 次 電子放出比曲線の最大值の值を $700 \mathrm{eV}$ ，そのときの yield を 1.1 として曲線を描き值し, yield が 1 になる時のエネルギー をこの曲楾から求めると約 $700 \mathrm{eV}$ となる。(図6)

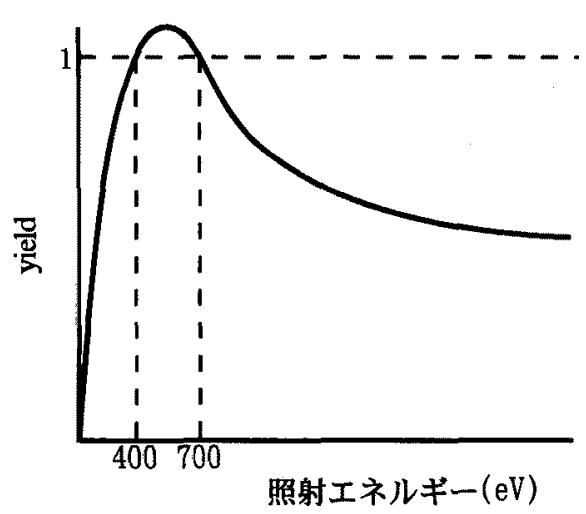

図6照射エネルギーに対する Ge の yield の変化(概形)

Fig. 6. Relationship between irradiation energy and yield of $\mathrm{Ge}$.

この $700 \mathrm{eV}$ という值が照射エネルギーと表面電位の差に なるものとした場合に予測される表面電位と比較して，測 定された表面電位は，実験で使用したどの照射エネルギー においても絶対值で低い值となっている。

さらに，表面電位の值に対して，どの程度のエネルギー の電子線照射が行われれば帯電を緩和することができるの かを調べるために， $5 \mathrm{keV}$ 程度までの電子線を照射し，あら かじめ- $470 \mathrm{~V}$ から $-2580 \mathrm{~V}$ までの電位に帯電させた試料に 電流密度 $1 \mathrm{nA} / \mathrm{cm}^{2}$ の電子線を照射し，照射エネルギーを $100 \mathrm{eV}$ から上昇させていった場合に，電位の緩和が始まった 時点の照射エネルギーを測定した結果を図7に示す。 


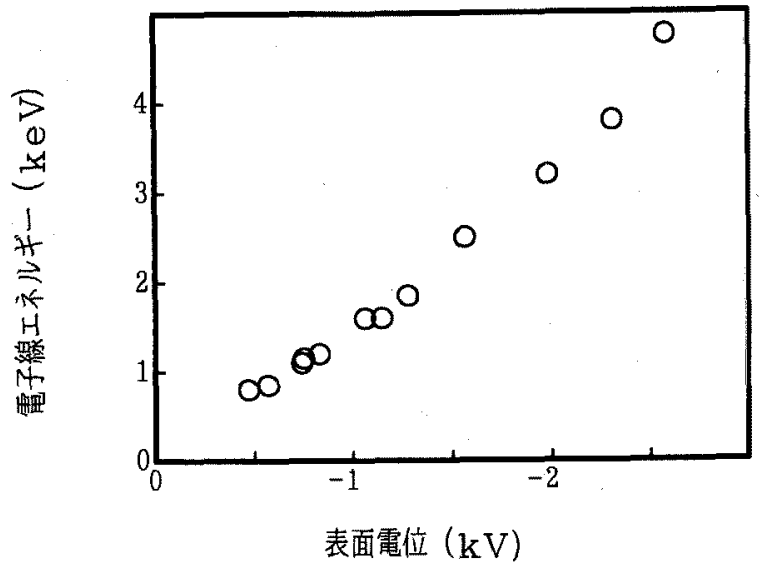

図7 Ge10nm 蒸着 FRP の表面電位緩和開始時の電子線 エネルギーと表面電位の関係

Fig. 7. Relationship between energy of electron beam at beginning of relaxation of surface potential of FRP with $\mathrm{Ge}$ of $10 \mathrm{~nm}$ thick.

この結果から，-2.5kV 程度までの带電をした Gel0nm 蒸 着 FRP 試料に対して，どの程度のエネルギーの電子線を照 射すれば，電位の緩和ができるかの目安を得ることができ る。ただし，緩和開始時の照射エネルギーを測定した後， さらに照射を継続した場合， $2.3 \mathrm{keV}$ 以上のエネルギーで緩 和が始まる場合には，照射を続けても電位は $0 \mathrm{~V}$ までは緩和 されなかった。

〈3.2〉 Ge50nm 蒸着 FRP の結果ここような試料の差異 による帯電特性への影響を検討するために，Ge 蒸着膜厚 $50 \mathrm{~nm}$ の試料を用いて同様の実験を行った。電子線照射電流 密度 $\ln \mathrm{A} / \mathrm{cm}^{2}$ で 1 分間照射を行った場合の表面電位を図8に 示す。

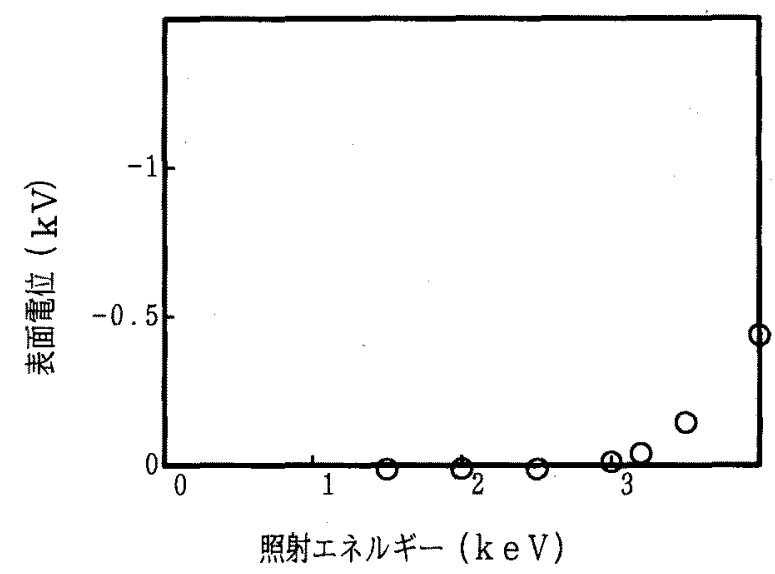

図8照射エネルギーと Ge50nm 蒸着 FRP の表面電位の 関係

Fig. 8. Relationship between irradiation energy and surface potential of FRP with Ge of $50 \mathrm{~nm}$ thick.
照射エネルギーが $2.4 \mathrm{keV}$ までは, 表面電位がわずかに正 か，ほぼ零電位になっており，さらにエネルギーが上昇す るにつれて表面電位の絶対值も徐々に上昇しているが, 照 射エネルギーの上昇分に比べると，かなり小さ值となっ ている。そしてこれらの $3 \mathrm{keV}$ 以上の照射エネルギーでの表 面電位は Ge10nm の場合よりもかなり低い值となっている。 これは， $\mathrm{Ge}$ 蒸着膜の存在が，表面電位の上昇を抑制する効 果があることを示している。

また，表面を約一 $1 \mathrm{kV}$ に帯電させた試料に対して， $2 \mathrm{keV，}$ $0.1 \mathrm{nA} / \mathrm{cm}^{2}$ の電子線照射を行った場合の表面電位の時間変化 を測定した結果を図9に示す。帯電の除去効果も, Ge10nm 蒸着 FRP と比較して短時間で現れており，帯電電圧の抑制 および帯電の緩和効果に関しては Ge 蒸着膜厚依存性がある ことが示された。

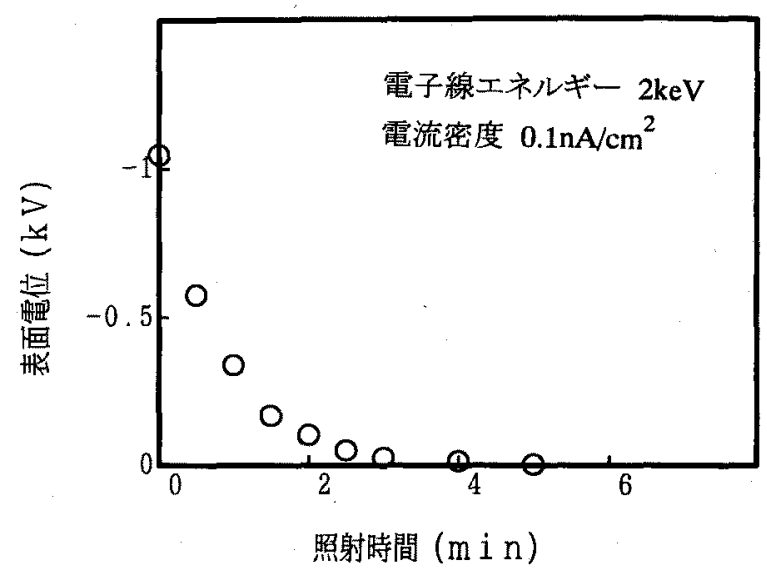

図9帯電させた Ge50nm 蒸着 FRP に電子線を照射した ときの表面電位の時間変化

Fig. 9. Time variation of surface potential of pre-charged FRP with Ge of $50 \mathrm{~nm}$ thick irradiated by electron beam.

<3.3> CFRP の結果ＣFRP 試料に対して，照射エネ ルギーを 5 および $10 \mathrm{keV}$ とし，電流密度を $1 \mathrm{nA} / \mathrm{cm}^{2}$ とした 場合の試料表面電位の時間変化を, 図10に示す。両者を比 較すると，照射エネルギーに $5 \mathrm{keV}$ の差があっても，到達表 面電位の值は, 数百 V しか差がなく, また, 到達電位の值 自体が絶対值で $700 \mathrm{~V} \sim 1200 \mathrm{~V}$ 程度の低いものとなっている。 FEP P PET の場合には，照射エネルギーと表面電位との差 は，約 $2 \mathrm{kV}$ 程度の值 ${ }^{(2)}$ であったことと比較すると，CFRPの 帯電特性は，単一の高分子材料とは大きく異なっている。

一般に試料の導電率が大きな試料の場合には，試料中を 表面から背面の接地された電極へと流れる導電電流が大き いために，電子線照射停止後の表面電位の緩和速度が早い。 しかし，電子線照射停止後の電位の変化を測定した図11で は，表面電位の緩和速度は，FRP と比較して CFRP 試料は特 に早いとはいえない。したがって，CFRP が低い表面電位と なる原因は，導電電流によるものではないものと判断され る。これらの結果から，CFRP は炭素繊維が含まれる高分子 


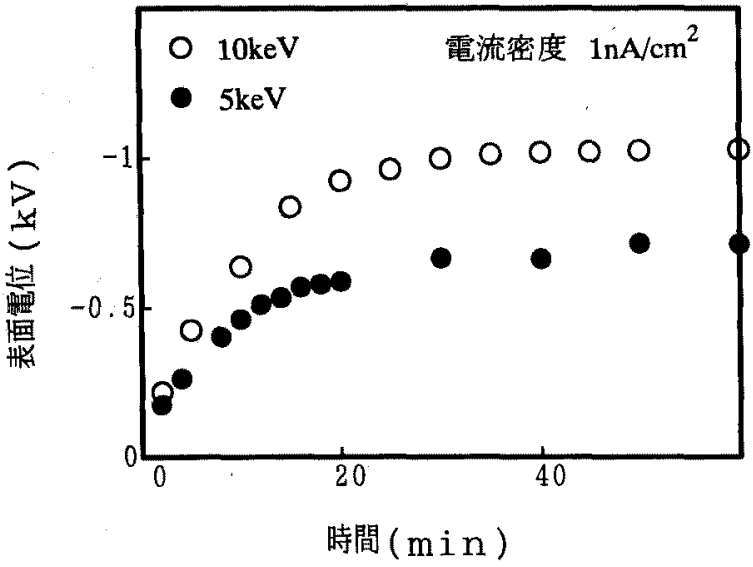

図10 CFRP 試料の表面電位の時間変化

Fig. 10. Time variation of surface potential of CFRP irradiated by electron beam of 5 and $10 \mathrm{keV}$.

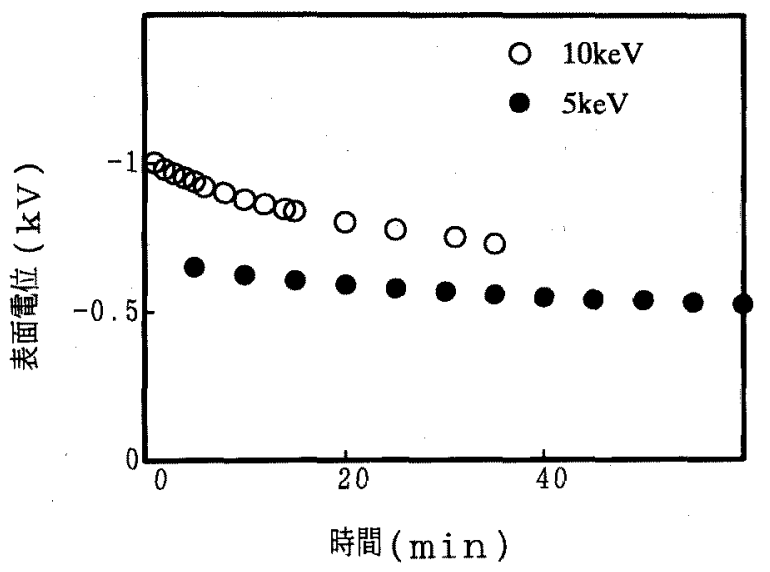

図11 CFRP 試料の表面電位の緩和

Fig. 11. Relaxation of surface potential of CFRP.

複合材料であるが，本研究で用いたものについてはバルク としての導電率は大きくはなく，したがって表面電位の值 の決定においては別の要因が支配的であることになる。さ らに，CFRP 試料では FEP などの単一の高分子材料と比較し て，電子線照射を受けた場合に表面電位の絶対值が小さい 值を保つ特性を持っていることが示された。

<3.4> 帯電機構の検討電子が物質に照射された場合の 入射電子のエネルギーが零となる物質層の厚さ（実用飛 程）の近似式を，Katzと Penfold は照射される電子のエネル ギーが低い範囲(<3MeV)で(1)式のように示している ${ }^{(4)}$ 。

$R \rho=412 E^{n}\left[\mathrm{mg} / \mathrm{cm}^{2}\right]$

$n=1.265-0.0954 \log E$

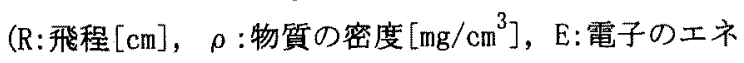
ルギー $[\mathrm{MeV}])$

これにより， $\mathrm{Ge}$, シリコン, アルミニウムおよび比重が 0.9 程度であるエポキシ樹嗮について，電子の飛程を求めると， 図12のようになる。

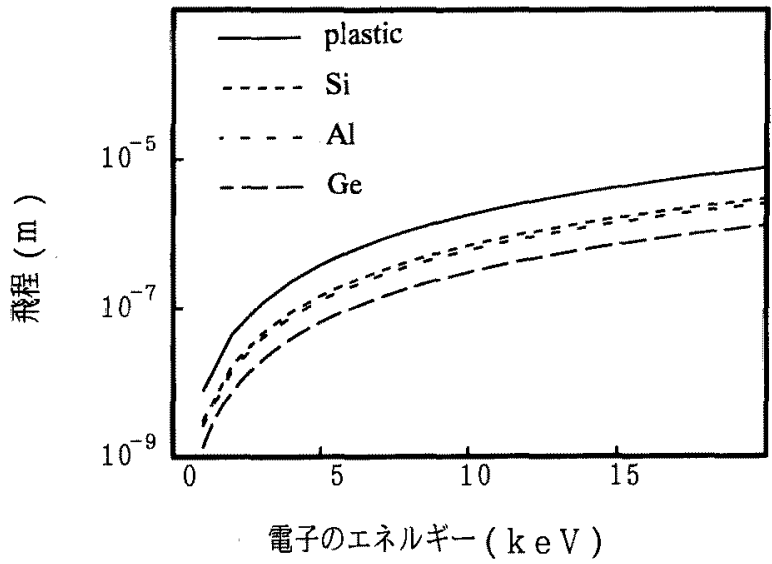

図12 電子のエネルギーと飛程の関係

Fig. 12. Relationship between electron energy and depth of electron penetration.

これより $\mathrm{Ge}$ 蒸着 FRP の場合は, $\mathrm{Ge}$ 蒸着層の厚さが $10 \mathrm{~nm}$ のとき約 $2.4 \mathrm{keV}, 50 \mathrm{~nm}$ のとき約 $4.5 \mathrm{keV}$ の照射エネルギー までは，電子線は FRP 層には届かず，Ge 蒸着層にとどまる ことになる。

Ge 单体に電子線を照射した場合には，照射開始直後の表 面電位が上舁していない時には，試料表面における電子線 のエネルギーは，接地電位に対するものと同じとなるが， 試料表面電位が上昇してくるにつれ，試料に対して電子の 持つエネルギーは减少し，図6における yield が 1 を越える時 の照射エネルギー約 $700 \mathrm{eV}$ になった時点で試料への電子線 の入射はなくなり，電位上昇もその時点で停止することに なる。したがって, Ge 单体の場合, 接地電位へ流れる導電 電流が十分に小さい場合には表面電位は電子線照射エネル ギーから約 $700 \mathrm{~V}$ を引た值となるはずである。FEP や PET などの高分子材料単体を用いた場合でも，yield が 1 を越え る時の照射エネルギーと電子線エネルギーとの差が表面電 位になるという測定結果が報告されている。これに対して， $\mathrm{Ge}$ 蒸着 FRP は飛程の計算結果では電子は $\mathrm{Ge}$ 層内にとどま るにもかかわらず, Ge 単体の場合に予想される表面電位よ りも絶対値で低い表面電位を示すといら測定結果が得られ ている。このような現象の機構には，今回用いた試料が導 電性を持つ薄い蒸着膜と, その下の絶縁材料基板との複合 材料であることが関係している可能性が考えられよう。

このような電子線照射による帯電特性が， $\mathrm{Ge}$ 蒸着膜と FRP の組み合わせに特有のものであるのかを検討するため に，文献(2)で帯電特性の測定，検討が行なわれている厚さ $127 \mu \mathrm{m}$ の FEP フィルムにアルミニウム蒸着を行った試料 に対して $10 \mathrm{keV}, 1 \mathrm{nA} / \mathrm{cm}^{2}$ で電子線照射を行ない，5および 10 分後の表面電位を測定したところ, 表1のような結果が得 られ，アルミニウム蒝着 FEP は蒸着を行なわないFEP に比 ベて，表面電位が非常に小さな値となった。

Ge の遒電率は， $2.1 \mathrm{Sm}^{-1}$ であるが，このような半導体と， $\mathrm{Al}$ のような金属とを比較して，同様の傾向が得られたこと 
表1 FEP への電子線照射による表面電位の変化

Table 1. Relationship between irradiation time and surface potential of FEP.

\begin{tabular}{c|c|c}
\hline & 5 分 & 10 分 \\
\hline アルミニウム蒸着 & -702 & -718 \\
\hline 蒸着なし & -7981 & -8020 \\
\hline
\end{tabular}

単位 : V

から， $10 \mathrm{keV}, 1 \mathrm{nA} / \mathrm{cm}^{2}$ の照射条件では電子線照射による帯 電特性に関して, $\mathrm{Ge}$ 蒸着膜は $\mathrm{Al}$ 蒸着膜と同様の機構が働い ており, 半導体や金属の蒸着膜と高分子材料の複合構造が このような特性をもたらしているものと考えられる。

また, 金属蒸着膜のないCFRP においても, 低い表面電位 を維持する類似の特性があることから，炭素緎維と高分子 材料の複合材料についても同様の機構が働いている可能性 がある。いずれの試料の場合でも導電電流は小さいことか ら，2 次電子放出がこのような帯電特性に関連していると考 えることが可能である。

本研究でとりあげた試料について，5keV，1nA $/ \mathrm{cm}^{2}$ で 10 分間電子線照射を行なった場合の帯電電位測定結果をまと めて表2に示す。

表2 $5 \mathrm{keV}, 1 \mathrm{nA} / \mathrm{cm}^{2}$ で 5 分間照射後の表面電位の比較 Table 2. Comparison of surface potential of various samples irradiated by electron beam of $5 \mathrm{keV}, \ln \mathrm{A} / \mathrm{cm}^{2}$ for $5 \mathrm{~min}$.

\begin{tabular}{c|c}
\hline 試料 & 表面電位 $(\mathrm{kV})$ \\
\hline FRP & -3.4 \\
\hline FEP & -3.6 \\
\hline $\mathrm{Al}$ 板(厚さ $1 \mathrm{~mm})$ & -2.6 \\
\hline CFRP & -0.5 \\
\hline $\mathrm{Ge} 10 \mathrm{~nm}$ 蒸着 FRP & -2.4 \\
\hline $\mathrm{Ge50nm}$ 蒸着 FRP & -1.2 \\
\hline $\mathrm{Al}$ 蒸着 FEP & -0.5 \\
\hline
\end{tabular}

( ${ }^{*} \mathrm{Al}$ 板は, ガラス板上に設置し, 絶縁した状態で実験)

\section{4. おわりに}

人工衛星の構造材としての FRP に対する宇宙環境下での 帯電を検討するために, 真空容器を用いた電子線照射実験 を行い, Ge 蒸着 FRP に関する帯電特性を測定した。それに より, Ge 蒸着を行った場合には, FRP のみの場合に比較し て表面電位の絶対值が低くなり, 帯電しにくくなることが 明らかになった。

また, 一 $1 \mathrm{kV}$ に帯電した状態の Ge 蒸着 FRP に対して, $2 \mathrm{keV}$ 程度の電子線照射を行うと, 急速に帯電が緩和される ことがわかった。蒸着膜厚と帯電特性および, 帯電の緩和
特性には関連があり, 蒸着膜厚が 10 および 50nm の場合で は，厚いほうがより顕著な帯電の緩和効果が観察された。 電子線の飛程の計算結果から, $2 \mathrm{keV}$ 程度のエネルギーで訪 料に照射された電子は, 本研究で用いた厚さの $\mathrm{Ge}$ 蒸着膜厚 の条件では, Ge 膜内にとどまり, FRP 層には達しないにも かかわらず，実験による帯電特性測定結果は，Ge 単体の材 料で予想される帯電特性とは異なるものとなっている。こ のような帯電特性は, Ge 蒸着 FRP のみならず, アルミニウ ム蒸着 FEP フィルムにも見られた。また，炭素瀻維と高分 子材料の複合材料である CFRP においても，表面電位が低く 抑えられるといら結果が得られており，今後，電子線照射 による帯電特性に関して，金属蒸着膜を持つ材料や炭素緎 維を含む材料における 2 次電子放出等の影響を検討する必 要があるものと考えられる。

\section{謝辞}

奉験装置の製作ならびに CFRP 試料の帯電特性に関する実 験に携わっていただいた元大学院生の大谷淳一氏, 試料の 入手に便宜をおはかりいただいた(株)日本電気の安藤昌紀氏 に深謝いたします。

(平成 9 年 1 月 13 日受付, 平成 9 年 8 月 18 日再受付)

\section{文献}

(1) M. S. Gussenhoven and E. G. Mullen : "Geosynchronous Environment for Severe Spacecraft Charging", J. Spacecraft and Rockets, Vol. 20, p. 26 (1983)

（2）小松原, 石井, 津村, 北條 : 「電子線照射された 人工衛星表面材料上での帯電と放電のパラメー 夕」, 電学論 A, Vol.116-A, p. 592 (1996)

（3）応用物理学会編, 「応用物理データブック」, 丸善 (1994)

（4）日本学術振興会第 132 委員会編, 「電子・イオン ビームハンドブック」, 日刊工業新聞社 (1973)

小松原 実 (正員) 1959 年 6 月 15 日生。1984 年 3

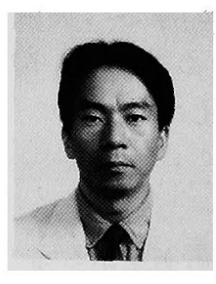
月京都大学大学院工学系研究科修士課程 修了。東京大学生産技術研究所勤務等を 経て, 1991 年 4 月岡山商科大学講師, 1994 年 4 月同助教授, 現在に至る。高 電圧工学, 情報処理に関する研究に従事。 平成 3 年度電気学会論文発表賞受賞。 
石井滕正) 1949 年 3 月 11 日生。1976 年 3

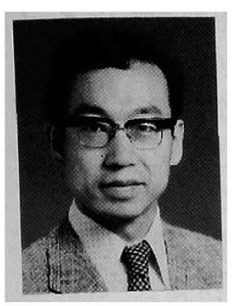

月東京大学大学院工学系研究科博士課 程修了。同年 4 月東京大学助教授, 1992 年 7 月同教授, 現在に至る。工学 博士。主として, 自然雷, 系統絶縁, 高電圧現象の測定に関する研究に従事。 1988 年度日本大気電気学会学術研究賞 受賞。平成元， 2 年度東京支部評議員。 IEEE Senior Member。AGU, CIGRE, 日 本大気電気学会等会員。 